\title{
Postmortem detection of inapparent myocardial infarction
}

\author{
J. G. McVIE \\ From the Department of Pathology, University of Edinburgh
}

SYNOPSIS Two methods of detecting early inapparent myocardial infarcts have been studied and their value in diagnostic practice compared.

The better method proved to be the determination of the potassium to sodium ratio (ionic ratio) which falls in infarcted tissue within minutes of the onset of anoxia. The second method was nitro blue tetrazolium staining of gross sections of myocardium which revealed any infarct older than three and a half hours. As staining is dependent upon enzyme activity, the latter method is disturbed by autolysis. It was shown, on the other hand, that the ionic ratio $\left(\mathrm{K}^{+} / \mathrm{Na}^{+}\right)$was not affected by autolysis and was therefore well suited to forensic practice.

Sixteen non-infarcted control hearts, plus the nine from cases of sudden death due to causes other than myocardial infarction, all yielded high ionic ratios $\left(\mathrm{K}^{+} / \mathrm{Na}^{+}\right)$, average $1 \cdot 4$, and stained normally with tetrazolium (the normal controls). Positive control was provided by 20 histologically proven infarcts of which the ionic ratios $\left(\mathrm{K}^{+} / \mathrm{Na}^{+}\right)$were all low (average 0.7). Histochemical staining with tetrazolium delineated infarcted areas in each case.

In a series of 29 sudden deaths, a cause of death other than myocardial infarction was found at necropsy in nine, mentioned above as normal controls. The remaining 20 hearts were not infarcted histologically, but were shown to be infarcted by examination of the ionic ratios $\left(\mathrm{K}^{+} / \mathrm{Na}^{+}\right)$. These ratios were low (average $\left.0 \cdot 8\right)$ including three borderline ratios. Con. firmatory evidence of infarction included nitro blue tetrazolium staining which revealed infarcts in 10 of the 20 cases, and clinical and necropsy observations.

The ionic ratio $\left(\mathrm{K}^{+} / \mathrm{Na}^{+}\right)$decreases as the age of the infarct increases for at least 24 hours. Thereafter as healing proceeds, the ratio gradually reverts to normal. Thus, previous infarction and replacement fibrosis do not significantly alter the ionic ratio $\left(\mathrm{K}^{+} / \mathrm{Na}^{+}\right)$. Nor is it changed by left ventricular hypertrophy, the presence of congestive cardiac failure, or digitalis therapy.

It is suggested that macroscopic tetrazolium staining is a useful screening test for early inapparent myocardial infarcts. In cases where no infarct is delineated with that method estimation of the ionic ratio $\left(\mathrm{K}^{+} / \mathrm{Na}^{+}\right)$should be carried out on myocardium removed from standard areas on the anterior and posterior left ventricular walls.

Sudden death can be caused by an ischaemia of the myocardium. If death is rapid an infarct may not be detected at necropsy. Its presence can be presumed from circumstantial evidence only. Even the finding of fresh thrombus occluding a coronary artery is not proof of subsequent infarction. Indeed Baroldi (1965) suggests that Received for publication July 1969. thrombosis may be a terminal event whose significance depends on the degree of collateral supply. Often the pathologist's diagnosis has to depend on a clinical history, and in sudden collapse even that may not be available.

At necropsy, naked-eye or histological examination can be valid if 12 hours or more have elapsed between the onset of symptoms and death. 
The truly objective histological evidence, polymorphonuclear invasion, usually takes over 18 hours to develop.

Two methods, one histochemical, one biochemical, have been described to assist in the recognition of early infarcts. The histochemical technique detects the loss of certain intracellular enzymes shortly after cell death. Thus microscopic (Nachlas and Shnitka, 1963; Morales and Fine, 1966) and macroscopic (Ramkissoon, 1966) stains for various dehydrogenases have been applied to early infarcts. Colourless nitro blue tetrazolium (Nitro BT) is reduced to a blue formazan by cellular dehydrogenases. Healthy cells therefore stain blue and those damaged by infarction do not. An infarct, some hours old, may be delineated easily to the naked eye on a transventricular slice of heart incubated with Nitro BT, provided that the cellular enzymes in the surrounding healthy tissue have not been inactivated by autolysis.

The biochemical method (Zugibe, Bell, Conley, and Standish, 1966) makes use of a change in the ratio of potassium ion concentration to sodium ion concentration ('ionic ratio' $\mathrm{K}^{+} / \mathrm{Na}^{+}$) in the myocardial infarct. It is known that potassium ions leave dead cells very rapidly due to their small molecular size (Russell, Crafoord, and Harris, 1961; Woodin and Wieneke, 1964). Moreover as potassium ions leak out through the inactivated cell membrane sodium ions move in the opposite direction into the cells. Providing that the venous return remains satisfactory the migrating potassium ions will escape from the infarcted area. Simultaneously the sodium concentration of the tissue is increased (Jennings, Sommers, Kaltenbach, and West, 1964). Obviously the ionic ratio $\left(\mathrm{K}^{+} / \mathrm{Na}^{+}\right)$in the infarcted myocardium will fall markedly since the numerator and denominator in the ratio change in opposite senses. Changes in the ionic ratio $\left(\mathrm{K}^{+} / \mathrm{Na}^{+}\right)$have been recorded in the dog's myocardium as early as 10 minutes after coronary artery ligation (Zugibe et al, 1966). The biochemical method is therefore highly applicable to the early infarct.

Both gross Nitro BT staining and the ionic ratio $\left(\mathrm{K}^{+} / \mathrm{Na}^{+}\right)$were used in this study to examine a series of hearts from patients dying within 12 hours of the onset of symptoms of a myocardial infarction. After all the laboratory data had been collected the two methods were compared with the age of the infarct as suggested by the clinical history and necropsy findings. In this way their value as tests of early infarction was gauged.

\section{Methods}

Sixty-five hearts obtained from necropsies on patients who died in the Royal Infirmary of
Edinburgh were examined. Twenty-nine of them were from cases of sudden death withim 12 hours of the onset of symptoms suggestive of myocardial infarction. A group of 20 clinically proven myocardial infarctions provided positive controls and a random series of 16 non-infarcted? hearts provided negative controls.

The coronary arteries, as far as their terminaf visible branches, were dissected from the under $\frac{0}{\sigma}$ lying myocardium and fixed in formol-saline $\overline{\bar{c}}$. They were then chopped into consecutive $2 \mathrm{~cm} \frac{\Phi}{\widetilde{\sigma}}$ long segments which were embedded and cup in longitudinal histological section. Next, seria\% transventricular slices, $4 \mathrm{~mm}$ thick, were madङ through the heart. On adjacent slices, grosstetrazolium staining, ionic ratio estimations, and histological sectioning were carried out.

DETERMINATION OF THE IONIC RATIO $\left(\mathrm{K}^{+} / \mathrm{Na}^{+}\right) \dot{\omega}$ Samples for estimating ionic ratio $\left(\mathrm{K}^{+} / \mathrm{Na}^{+} \mathrm{\delta}_{\text {S }}\right.$ were taken from defined areas on the anterior an $\delta^{\phi}$ posterior walls of the left ventricle. On the anteriop wall pieces were removed from a standard point deep to the anterior descending branch of the left coronary artery and $5 \mathrm{~cm}$ from its origin. However, on the posterior left ventricula $\overrightarrow{0}$ wall the arterial supply is insufficiently constant tọ act as a reliable reference and the coronary sinus was used instead. Accordingly, sample of the left ventricle were taken at a level of $6 \mathrm{cn} 5$ from it and adjacent to the interventriculag septum.

In each case the block removed was a centi metre cube of muscle approximately $1 \mathrm{~g}$ i weight, and it was immediately trimmed of alf fat, blood clot, pericardium, and endocardium

When necessary the tissue was wrapped i aluminium foil and stored at $-20^{\circ} \mathrm{C}$ : exper ments failed to show any effect of storage op the ionic ratio.

The trimmed tissue was chopped into sma pieces and weighed on a torsion balance. $\mathrm{De}^{3}$ ionized distilled water, which was used to was all instruments and containers, was added tQ give a weight to volume ratio of $1: 20$. The hear. mixture was homogenized for 10 minutes at room temperature in a Waring blender, followed by five minutes in a ground glass homogenize The cell debris was spun down at 1,000 rpret for 10 minutes and analysis of sodium and potassium was carried out on 1 in 10 and 1 in $5 Q$ dilutions of the supernatant, respectively. Th5 dilutions were tested against both separate and mixed standards of sodium and potassium in an EEL flame photometer.

GROSS TETRAZOLIUM STAINING The method described by Ramkissoon (1966 was used. A solution of Nitro BT, 1 paro phosphate buffer $p H$ 7.4, 1 part, and distilles. water, 8 parts, was warmed to $37^{\circ} \mathrm{C}$. The my 
cardial slices were then immersed in it and the temperature was maintained for 30 minutes. Any lesions noted were sketched for inclusion in the pathologist's notes.

\section{AUTOLYSIS STUDY}

Five pieces of normal myocardium were kept under different conditions for three weeks in sealed glass jars. In four of the jars, the myocardium was stored alone at $0^{\circ} \mathrm{C}, 5^{\circ} \mathrm{C}$, room temperature, and $37^{\circ} \mathrm{C}$ respectively. In the fifth jar the myocardium was immersed in water at a temperature of $5^{\circ} \mathrm{C}$. At intervals during the three weeks, an aliquot was cut from each sample for ion determination. The piece of heart kept at $37^{\circ} \mathrm{C}$ smelled so objectionably after one week that it had to be removed from the laboratory before the end of the experiment. The experiment was repeated with pieces of infarcted myocardium.

\section{Results}

IONIC RATIOS $\left(\mathrm{K}^{+} / \mathrm{Na}^{+}\right)$

\section{Normal hearts}

The 16 control hearts were free from any recent myocardial infarction though over half of them showed hypertrophy or chronic fibrosis (Table 1 ).

\begin{tabular}{lcll}
\hline Factor & $\begin{array}{l}\text { No. of } \\
\text { Cases }\end{array}$ & $\begin{array}{l}\text { Range of } \\
\text { Ratios }\end{array}$ & $\begin{array}{l}\text { Average } \\
\text { Ratio }\end{array}$ \\
\hline $\begin{array}{l}\text { Left ventricular } \\
\text { hypertrophy }\end{array}$ & 8 & & \\
Chronic fibrosis & 6 & $1 \cdot 3-1 \cdot 7$ & $1 \cdot 5$ \\
Congestive cardiac failure & 10 & $1 \cdot 2-1 \cdot 6$ & $1 \cdot 4$ \\
Digitalis therapy & 5 & $1 \cdot 1 \cdot 1 \cdot 6$ & $1 \cdot 5$ \\
Hyperkalaemia & 2 & $1 \cdot 1 \cdot 1 \cdot 6$ & $1 \cdot 4$ \\
External cardiac massage & 1 & $1 \cdot 1-1 \cdot 5$ & $1 \cdot 3$ \\
& 25 & $1 \cdot 3$ & $1 \cdot 3$ \\
Total & & $1 \cdot 1-1 \cdot 7$ & $1 \cdot 4$ \\
\hline
\end{tabular}

Table I Effects of various factors on ionic ratios $\left(\mathrm{K}^{+} / \mathrm{Na}^{+}\right)$in normal control hearts

They were taken at random from routine necropsies. The average ionic ratio $\left(\mathrm{K}^{+} / \mathrm{Na}^{+}\right)$was $1 \cdot 4$ (Table II). There are various different figures

\begin{tabular}{llll}
\hline Group of Hearts & $\begin{array}{l}\text { No. of } \\
\text { Cases }\end{array}$ & $\begin{array}{l}\text { Range of } \\
\text { Ratios }\end{array}$ & $\begin{array}{l}\text { Average } \\
\text { Ratio }\end{array}$ \\
\hline Normal & 25 & $1 \cdot 1-1 \cdot 7$ & $1 \cdot 4$ \\
Proven infarcts & 20 & $0 \cdot 4-1 \cdot 1$ & $0 \cdot 7$ \\
Suspected infarcts & 20 & $0 \cdot 3-1 \cdot 1$ & $0 \cdot 8$ \\
\hline
\end{tabular}

Table II Ionic ratios $\left(\mathrm{K}^{+} / \mathrm{Na}^{+}\right)$of all hearts examined in the series

for ionic ratios $\left(\mathrm{K}^{+} / \mathrm{Na}^{+}\right)$in normal left ventricle (Table III). All the values quoted were determined by different techniques and the standard devia-

\begin{tabular}{lll}
\hline Reference & Region of Heart & Ionic Ratio \\
\hline \multirow{2}{*}{ Sherrod (1947) } & Right atrium & $1 \cdot 4$ \\
& Left atrium & $1 \cdot 25$ \\
& Right ventricle & $1 \cdot 0$ \\
Wilkins and Cullen (1933) & Left ventricle & $1 \cdot 0$ \\
& Left ventricle & $3 \cdot 0^{1}$ \\
Holland (1964) & Right ventricle & $2 \cdot 0$ \\
Brodie (1951) & Left ventricle & $1 \cdot 9^{1}$ \\
Iseri (1952) & Left ventricle & $1 \cdot 9^{1}$ \\
Dünhölter and Jansen (1965) & Left ventricle & $1 \cdot 7^{1}$ \\
& Right ventricle & $0.8^{1}$ \\
Zugibe et al (1966) & Left ventricle & $1 \cdot 5^{1}$ \\
Clarke and Mosher (1952) & Left ventricle & $2 \cdot 8$ \\
& Left ventricle & $2 \cdot 05$ \\
Present work & Right ventricle & $1 \cdot 02$ \\
& Left ventricle & $1 \cdot 4$ \\
\hline
\end{tabular}

Table III Review of ionic ratios of the normal human heart

${ }^{1}$ Denotes ratios calculated from author's absolute values.

tions vary accordingly. The deviation calculated in the ionic ratio $\left(\mathrm{K}^{+} / \mathrm{Na}^{+}\right)$for the results was \pm 0.05 . The differences in electrolyte composition of the chambers of the heart are clearly brought out in the table and justify confining the analysis to standard regions.

\section{Proven myocardial infarcts}

In 20 hearts which showed macroscopic and microscopic features of infarction the range of ionic ratios $\left(\mathrm{K}^{+} / \mathrm{Na}^{+}\right)$was from 0.4 to 1.1 (average 0.7). All the hearts came from patients who had suffered from chest pain or dyspnoea or who had collapsed more than 12 hours before death. Polymorphonuclear infiltration and loss of nuclei in necrotic cells were taken to be significant histological features of infarction.

It seemed that the critical value of the ionic ratio $\left(\mathrm{K}^{+} / \mathrm{Na}^{+}\right)$between the normal myocardium on the one hand and the infarcted on the other was $1 \cdot 1$ (Table II). A ratio above $1 \cdot 1$ could be taken as normal, whereas values below $1 \cdot 1$ came from myocardial infarcts.

\section{Suspected infarcts}

Twenty-nine cases of suspected myocardial infarction leading to death within 12 hours were scrutinized. Nine of these had normal ionic ratios $\left(\mathrm{K}^{+} / \mathrm{Na}^{+}\right)$, and were proved at necropsy to have died from causes other than myocardial infarction (Table IV). The ionic ratios $\left(\mathrm{K}^{+} / \mathrm{Na}^{+}\right)$ of the remaining 20 hearts were lower than $1 \cdot 1$, ie, the ratios confirmed the presence of in-

\begin{tabular}{ll}
\hline Cause of Death & Number of Cases \\
\hline Pulmonary embolism & 3 \\
Cerebral haemorrhage & 3 \\
Bronchopneumonia & 2 \\
Acute pulmonary oedema & 1 \\
Total & 9
\end{tabular}

Table IV Cause of sudden death in control hearts 
farction. It is in this group that the electrolytic analysis is most important since there was a lack of evidence to lead the pathologist to any other diagnosis. By the same token, it is difficult to prove that the patients had died from myocardial ischaemia as none of their hearts revealed definite microscopic signs of infarction. All that can be offered is the careful elimination of other causes of death, and proof of specificity of the test by reference to histologically established infarcts: circumstantial, as opposed to microscopic, evidence in favour of the diagnosis is shown in Table V. Each patient included

\begin{tabular}{lc}
\hline Items of Evidence & No. of Cases \\
\hline & \\
Collapse and shock & 12 \\
Chest pain & 6 \\
Postoperative death & 2 \\
Congestive cardiac failure & 13 \\
Electrocardiographic evidence & 4 \\
Arrhythmias & 5 \\
Raised serum transaminases & 2 \\
History of previous infarction & 9 \\
History of previous valvular disease & 4 \\
Coronary artery occlusion at necropsy & 11 \\
Delineation of infarct by Nitro BT stain & 10 \\
Total number of cases & 20 \\
\hline
\end{tabular}

Table V Circumstantial evidence in support of relationship of low ionic ratio to myocardial infarction

had at least two, and on average four, of the features in the left-hand column of the Table, eg, five cases had a history of chest pain and had fresh thrombus in a coronary artery, and five more were in cardiac failure and had an infarct revealed by tetrazolium staining. Only four patients were seen who had neither fresh coronary occlusion nor positive tetrazolium staining. One, however, had a history of chest pain and electrocardiographic changes of infarction. Two more were in a state of shock after sudden collapse, and received external cardiac massage, of which the influence on the ionic ratio is unknown. Finally, a patient who collapsed suddenly had aortic and mitral valve disease, hypertensive heart disease, chronic renal disease, and congestive cardiac failure. Both surgical deaths were proved to be due to inadequate perfusion of the coronary arteries while the patients were undergoing cardiopulmonary bypass operations.

In three hearts the coronary arteries were occluded at one of the ostia. The obstruction in one case was a calcific valvular vegetation, in another it was a septic valvular vegetation, and in the third it was a thrombus arising from an aortic valve prosthesis. Such coronary ostial lesions would be expected to produce early infarcts of the appropriate areas of the left ventricle, and electrolyte estimations exactly confirmed ischaemic changes in the predicted sites. With such early infarcts a notable feature was the normality of the ionic ratios $\left(\mathrm{K}^{+} / \mathrm{Na}^{+}\right)$ found in the unaffected part of the ventricle. $C$ In older infarcts in the series the surrounding? normal-looking myocardium showed slight alterations in the ratio in the direction of in-0 farction. The reasons for this will be explored $\underline{\underline{\sigma}}$ in the discussion.

\section{GROSS TETRAZOLIUM STAINING}

Areas of early infarction, not visible to the naked eye, are revealed in a transventricular section $\bar{\Omega}$ of the heart by failure to stain purple after in cubation with Nitro BT. Positive results (absence of staining) were obtained in all infarcts older $\overrightarrow{0}$ than 12 hours. Ten cases out of 20-all of shorterduration than 12 hours and inapparent at necropsy-gave a conclusive result (Table VI) $\frac{\overline{8}}{\mathrm{O}}$ The earliest inapparent infarct revealed by the stain was three and a half hours old.

\begin{tabular}{|c|c|c|c|}
\hline & $\begin{array}{l}\text { Nitro } \\
\text { Staining } \\
\text { Positive }\end{array}$ & Negative & Total \\
\hline $\begin{array}{l}\text { Number of cases } \\
\text { Range of ratios } \\
\text { Average ratio }\end{array}$ & $\begin{array}{l}10 \\
0 \cdot 3-0 \cdot 9 \\
0 \cdot 7\end{array}$ & $\begin{array}{l}10 \\
0 \cdot 8-1 \cdot 1 \\
0.9\end{array}$ & $\begin{array}{l}20 \\
0 \cdot 3-1 \cdot 1 \\
0 \cdot 8\end{array}$ \\
\hline
\end{tabular}

Table VI Comparison of nitro blue tetrazolium staining and ionic ratio $\left(\mathrm{K}^{+} / \mathrm{Na}^{+}\right)$in early myocardial infarcts

A case of cardiomyopathy gave an interesting appearance on incubation: small, rounded pink foci, 6 to $8 \mathrm{~mm}$ in diameter, were scattered against a purple backcloth of healthy tissue. No viruswas cultured from the tissue and the aetiologyọ remains unknown. The ionic ratio $\left(\mathrm{K}^{+} / \mathrm{Na}^{+}\right)$ was below normal, presumably due to the col? lective effect of the multiple foci of necrosis.

\section{AUTOLYSIS STUDY}

The results of the autolysis experiments are summarized in Table VII. The ionic ratios $\left(\mathrm{K}^{+}\right.$ $\mathrm{Na}^{+}$) were reliable in the frozen tissue samples근.

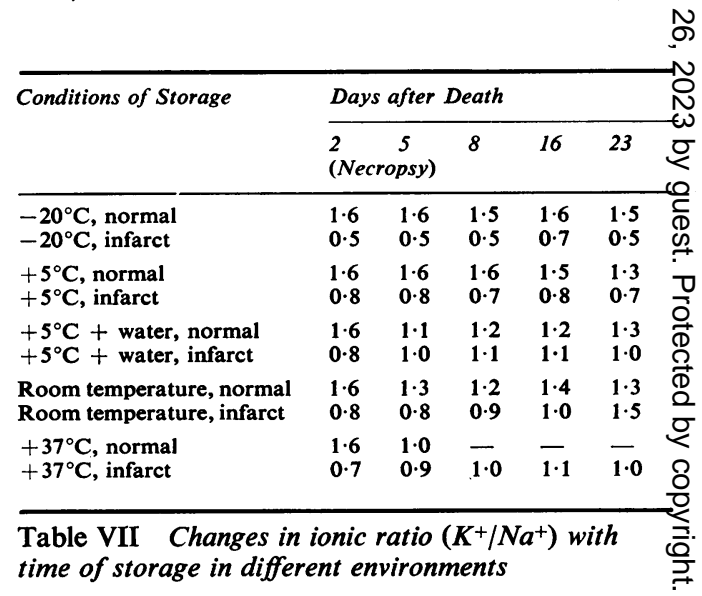


Similarly, when kept at $5^{\circ} \mathrm{C}$, results were consistently accurate. The changes in the tissues at room temperature and at $37^{\circ} \mathrm{C}$ follow the pattern of those in water at $5^{\circ} \mathrm{C}$. Thus the normal myocardium lost some sodium together with at least twice as much potassium. The ionic ratio $\left(\mathrm{K}^{+} / \mathrm{Na}^{+}\right)$, therefore, dropped. The infarcted hearts, on the other hand, lost their excess of sodium, and, having little potassium left to lose, showed an increase in the ionic ratio $\left(\mathrm{K}^{+} / \mathrm{Na}^{+}\right)$. The changes are paralleled by the onset of liquefaction in the heart muscle. The ionic ratios $\left(\mathrm{K}^{+} / \mathrm{Na}^{+}\right)$in the three groups just compared were all approaching unity, perhaps due to attainment of equilibrium with the surrounding liquids.

\section{Discussion}

IONIC SHIFTS IN MYOCARDIAL INFARCTS The electrolyte changes in myocardial infarcts found during this work are supported by other investigations. By producing coronary insufficiency in dogs, Crout and Jennings (1957) noted a loss of potassium from the ischaemic tissue, first detectable an hour after induction of the infarct. Lowry, Gilligan, and Hashings (1942), also working with dogs, noticed an increase in the sodium content of the infarcted myocardium which accompanied potassium depletion. By cannulating the coronary sinus of dogs, Dennis and Moore (1938) were able to measure a rise in the serum potassium level of blood samples removed from it seven minutes after ligation of a coronary artery.

Russell et al (1961) calculated that oedema fluid provided less than a quarter of the excess sodium ions in an infarcted piece of myocardium. Therefore a rise in intracellular sodium concentration must account for the extra ions. The continued shift of sodium into the cells depends upon the ability of the collateral circulation to make it available to the extracellular fluid. At the same time potassium ions are lost from the cells into the surrounding medium whence they gain the efferent vasculature and ultimately the coronary sinus (Dennis and Moore, 1938).

There are three important concepts of the ion exchange mechanism observed in the dying cell. First, Woodin (1960) claims that an increase in membrane permeability is the initial response of the cell to anoxia. Such an increase would permit sodium ions to move into the cell and potassium ions to move out as happens normally in the depolarization of muscle and nerve. In the normal living cell the activity of the 'sodium pump' expels sodium ions and thus opposes the ionic shifts of cell damage.

Supporting evidence comes from Elsbach and Schwartz (1959) who claim that potassium leaves the damaged cell two hundred times faster than normal. To explain so rapid a loss they consider $c$ that a gross increase in cellular permeability is necessary.

The second view is due to Judah and Ahmed (1964), who proposed that direct inhibition of the 'sodium pump' is the first step in the process of cell death. They state that calcium ions are $\overrightarrow{\overrightarrow{0}}$ mobilized from the cell membrane by injury and $\overrightarrow{0}$ that they inhibit the ATP-ases essential to the $\frac{\overline{0}}{}$ supply of energy to the pump. Judah and Ahmed $\frac{\overline{\bar{s}}}{\overline{5}}$ do admit, however, that when calcium ions leave $\varnothing$ the cell membrane it also becomes more permeable. Thus the theories of Woodin and Judah ${ }^{\infty}$ and Ahmed are complementary rather than $\vec{\circ}$ opposed.

The third concept also involves the loss of ${ }_{\sigma}^{\bar{\omega}}$ activity in the sodium pump. Cell lysosomes are thought to be disrupted within seconds of the onset of anoxia (Hirsch, Bernheimer, and $\stackrel{\omega}{\omega}$ Weissmann, 1963). Hydrolytic and other des- $i$ tructive enzymes are released and are thought to ${ }_{\mathcal{E}}$ inhibit the mechanisms of the sodium pump.

Apparently elements of all three theories might form the true mechanism of loss of potassium $\rightarrow$ and gain in sodium in the infarcted tissue.

\section{COMPARISON OF DIAGNOSTIC AIDS}

\section{Ionic ratios}

The measurement of the myocardial ionic $\stackrel{\otimes}{\otimes}$

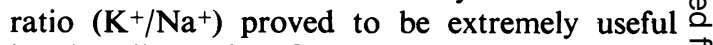
in the diagnosis of early infarcts. Seventeen $\overrightarrow{0}$ out of 20 cases showed a clear-cut difference between normal and abnormal ionic ratios, viz, less than 1.0. Three had ratios of $1 \cdot 1$, whereas one of 25 control hearts had that value. The remaining 24 were greater than $1 \cdot 2$. The figures suggested that the age of an infarct, at least for the first 12 hours, could be estimated roughly by the value of the ionic ratio $\left(\mathrm{K}^{+} / \mathrm{Na}^{+}\right)$; as the lesion ages the ionic ratio $\left(\mathrm{K}^{+} / \mathrm{Na}^{+}\right)$becomes more abnormal.

Also the extent of the infarct as measured by the ionic ratio $\left(\mathrm{K}^{+} / \mathrm{Na}^{+}\right)$becomes greater with age. It seems that in ischaemia ionic shifts $\widetilde{\sigma}$ are not confined to the apparent infarct but $N$ take place also in the surrounding viable myo- N cardium. These changes are similar to those in the fresh infarct but take longer to appear and are not so pronounced.

Sampling five specific points in numerous infarcted hearts, Iseri, Alexander, McCaughey, Boyle, and Myers (1952) calculated that the ionic ratios $\left(\mathrm{K}^{+} / \mathrm{Na}^{+}\right)$were always lower than those of his control group, independent of the site or size of the infarct.

It may be that the changes described are due to a compensatory effect by myocardium adjacent to an infarct in an attempt to stabilize the cation distribution in the extracellular fluid. A simpler solution may be that the apparently normal 
myocardium is, in fact, ischaemic. Perhaps obvious infarcts are much more extensive than is usually thought, and the abnormal electrolytes are demonstrating early, possibly terminal, ischaemia throughout the myocardium.

The autolysis study points out that the ionic ratio $\left(\mathrm{K}^{+} / \mathrm{Na}^{+}\right)$remains an accurate guide to normality or infarction until autolysis has advanced to the stage of liquefaction (Table VII). In addition, storage at $0^{\circ} \mathrm{C}$ maintains the electrolyte state of the tissue for long periods.

Several pathological states may influence the ionic composition of the myocardium, eg, congestive cardiac failure (Calhoun and Harrison, 1931), digitalis administration (Daniel, 1964), and left ventricular hypertrophy (Ledingham, 1957). It will be noticed from Table I that none of the above seem to have affected the ratios in the control group. Some of the hearts suffered from more than one of the conditions mentioned without significant disturbance of the ionic $\operatorname{ratios}\left(\mathrm{K}^{+} / \mathrm{Na}^{+}\right)$.

The findings are in keeping with those of Scott (1930), Lowry et al (1942), and Bliss and Adolph (1963) who claim that although sodium concentrations may rise in congestive heart failure no potassium is lost, and the ionic ratio $\left(\mathrm{K}^{+} / \mathrm{Na}^{+}\right)$ is not therefore significantly altered. Further, Klaus (1961) and Bliss and Adolph (1963) refute the suggestion that correct digitalis therapy causes loss of potassium from the myocardium. They believe that potassium is lost only in overdosage. Confirmation comes from the findings that the extrasystoles of digitalisintoxication can be abolished by potassium supplements (Sampson, Alberton, and Kondo, 1943; Enselberg, Simmons, and Mintz, 1950). There is a similarity here to the findings of Sodi-Pollares (1961) and Mittra (1965), who recommend the use of potassium, insulin, and glucose in the arrhythmias of infarctions. However, recently, an MRC Working Party (1968) have discredited such a regime.

Finally, the method involved in determining ionic ratios $\left(\mathrm{K}^{+} / \mathrm{Na}^{+}\right)$is simple and can be carried out in under an hour. It is more economical to examine a batch of samples at one session. The method has also been modified slightly for autoanalysis of the heart homogenates, with a considerable saving in labour.

\section{Gross histochemical staining}

Table VI shows that in 20 early infarcts the Nitro BT test was positive in half of the series. The 10 negative cases had histories of less than three and a half hours. It is appreciated that of necessity length of history may be inaccurate for some patients.

Mapping of the inapparent infarct was beautifully portrayed by the above technique, and provided simple correlation with the area of supply of an occluded coronary vessel or ECG findings when present. The method takes 30 minutes and is easily carried out in the necropsy room provided that a simple means of incubation is available. It is unfortunate invalidated by autolysis and thus is of less value than the ionic ratio in medico-legal practice

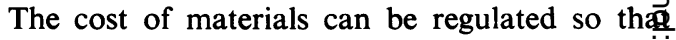
each test costs about three shillings.

I should like to thank Professor G. L. Montgomer and Dr S. Fletcher, of the Department of Patholog for their helpful advice and assistance. The pat ologists of the Royal Infirmary of Edinburgh kindby allowed me to use necropsy material.

\section{References}

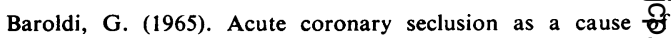
myocardial infarct and sudden coronary heart deatho Amer. J. Cardiol., 16, 859-880.

Bliss, A., and Adolph, R. J. (1963). Effect of experimental cóos gestive heart failure and acetyl strophanthidin on mypo cardial electrolyte and water content. Circulat. Res., 19 207-217.

Brodie, B. B. (1951). Measurement of total body water. Me med. Res., 4, 31-38.

Calhoun, J. A., and Harrison, T. R. (1931). Studies in congestixe heart failure. IX. The effect of digitalis on the potassit content of the cardiac muscle of dogs. J. clin. Invest., 暨 139-144.

Clarke, N. E., and Mosher, R. E. (1952). The water and electre content of the human heart in congestive heart failur with and without digitalization. Circulation, 5, 907-914.

Crout, J. R., and Jennings, R. B. (1957). An improved hist chemical method for the demonstration of potassiug. J. Histo-chem. Cytochem., 5, 170-177.

Daniel, E. E. (1964). Interconnection between active transp and contracture in uterine tissues. Canad. J. Physiad. Pharm., 42, 453-495.

Dennis, J., and Moore, R. M. (1938). Potassium changes \& functioning heart under conditions of ischemia and congestion. Amer. J. Physiol., 123, 443-447.

Dünhölter, J. H., and Jansen, H. H. (1965). Die Dignitat dS Kalium-und Natriumbestimmungen von Leichenorgane bei verschiedenen Erkrangkung des Stoffwechsels. Vir ows Arch. path. Anat., 339, 316-326.

Elsbach, P., and Schwartz, J. L. (1959). Studies on the sodium and potassium transport in rabbit polymorphonucleff leukocytes. J. gen. Physiol., 42, 883-898.

Enselberg, C. D., Simmons, H. G., and Mintz, A. A. (195\%). The effects of potassium upon the heart, with spectut reference to the possibility of treatment of toxic arrhy mias due to digitalis. Amer. Heart. J., 39, 713-728.

Hirsch, J. G., Bernheimer, A. W., and Weissmann, G. (1963) Motion picture study of the toxic action of stretolysi@s on leucocytes. J. exp. Med., 118, 223-227.

Holland, W. C. (1964). Ion distribution and myocardial metabolisfir as affected by cardiac glycosides. Circulat. Res., 14- \$ suppl. 2, 85-92.

Iseri, L. T., Alexander, L. C., McCaughey, R. S., Boyle, A. א్ and Myers, G. B. (1952). Water and electrolyte content ${ }^{-o f}$ cardiac and skeletal muscle in heart failure and myocardB? infarction. Amer. Heart.J., 43, 215-227.

Jennings, R. B., Sommers, H. M., Kaltenbach, J. P., and West J. J. (1964). Electrolyte alterations in acute myocardiet ischemic injury

Judah, J. D., and Ahmed, K. (1964). The biochemistry of sodi\& transport. Biol. Rev., 39, 160-193.

Klaus, W. (1961). In Proceedings of First International Pharma@ological Meeting, edited by W. Wilbrant, p. 111. Pergamon Press, New York.

Ledingham, J. M. (1957). Disturbances in water and electrolyde metabolism in experimental hypertension. Brit. med. Buफ", 13, 33-38.

Lowry, O. H., Gilligan, D. R., and Hashings, A. B. (1940). Histochemical changes in the myocardium of dogs folloq ing experimental temporary coronary arterial occlusie. Amer. J. Physiol., 136, 474-485.

Medical Research Council Working Party (1968). Potassiu@, glucose, and insulin treatment for acute myocard商 infarction. Lancet, 2, 1355-1360.

Mittra, B. (1965). Potassium, glucose and insulin in treatment myocardial infarction. Lancet, 2, 607-609. 
Morales, A. R., and Fine, G. (1966). Early human myocardial infarction: a histochemical study. Arch. Path., 82, 9-14.

Nachlas, M. M., and Shnitka, T. K. (1963). Macroscopic identification of early myocardial infarcts by alterations in dehydrogenase activity. Amer. J. Path., 42, 379-405.

Ramkissoon, R. A. (1966). Macroscopic identification of early myocardial infarction by dehydrogenase alterations. J. clin. Path., 19, 479-481.

Russell, R. A., Crafoord, J., and Harris, A. S. (1961). Changes in myocardial composition after coronary artery ligation. Amer.J.Physiol., 200,995-998.

Sampson, J. J., Alberton, E. C., and Kondo, B. (1943). The effect of potassium administration in relation to digitalis glycosides. Amer. Heart J., 26, 164-179.

Scott, L. C. (1930). The proportion of certain important inorganic constituents in the dying heart muscle. J. clin. Invest., 9, 463-474.

Sherrod, T. R. (1947). Effects of digitalis on electrolytes of heart muscle. Proc. Soc. exp. Biol. (N.Y.), 65, 89-90.

Sodi-Pallares, D. (1961). Posibilidad de un terapeutica de integracion ionica celular en los padecimentos, cardiovascu lares. Arch. Inst. Cardiol. Mèx., 31, 557-574.
Wilkins, W. E., and Cullen, G. E. (1933). Electrolytes in human tissues. III. A comparison of normal hearts with hearts showing congestive heart failure. J. clin. Invest., 12 , 1063-1074.

Woodin, A. M. (1960). Purification of two components of leucocidin from Staphvlococcus aureus. Biochem. J., 75, 158-165.

Woodin, A. M., and Wieneke, A. A. (1964). In Cellular Injury, a Ciba Foundation Symposium, edited by A. V. S. De Reuck and Knight, p. 30. Churchil, London.

Zugibe, F. T., Bell, P., Jr., Conley, T., and Standish, M. L. (1966). Determination of myocardial alterations at autopsy in the absence of gross and microscopic changes. Arch. Path., 81, 409-411. 